\title{
Antimicrobial activity and quality control of a formulation based on Libidibia ferrea
}

\section{after aging}

\author{
Atividade antimicrobiana e controle de qualidade de uma formulação à base de Libidibia ferrea \\ após envelhecimento
}

Actividad antimicrobiana y control de calidad de una formulación después del envejecimiento a

base de Libidibia ferrea

Received: 08/02/2021 | Reviewed: 08/13/2021 | Accept: 08/14/2021 | Published: 08/16/2021

\author{
Amanda Luzia Moreira de Souza \\ ORCID: https://orcid.org/0000-0001-8162-2538 \\ Federal University of Amazonas, Brazil \\ E-mail: amandinha_luzia@hotmail.com \\ Anselmo Junio Pedroso Matos \\ ORCID: https://orcid.org/0000-0002-9566-8542 \\ Federal University of Amazonas, Brazil \\ E-mail: anselmomatos.odonto@gmail.com \\ Wanderleia Monteiro de Souza \\ ORCID: https://orcid.org/0000-0002-0410-9391 \\ Federal University of Amazonas, Brazil \\ E-mail:wanderleiams@hotmail.com \\ Tatiane Pereira de Souza \\ ORCID: https://orcid.org/0000-0003-1164-2191 \\ Federal University of Amazonas, Brazil \\ E-mail: tpsouza@ufam.edu.br \\ Gisely Naura Venâncio \\ ORCID: https://orcid.org/0000-0001-9756-140X \\ Municipal Health Department, Brazil \\ E-mail: ginaura@gmail.com \\ Maria Fulgência Costa Lima Bandeira \\ ORCID: https://orcid.org/0000-0002-9847-5578 \\ Federal University of Amazonas, Brazil \\ E-mail: fulgencia@ufam.edu.br \\ Carina Toda \\ ORCID: https://orcid.org/0000-0003-1709-0877 \\ Federal University of Amazonas, Brazil \\ E-mail: carinatoda@yahoo.com.br \\ Ana Regina Casaroto Moreschi \\ ORCID: https://orcid.org/0000-0002-3851-4985 \\ Federal University of Amazonas, Brazil \\ E-mail: ana_casaroto@yahoo.com.br \\ Nikeila Chacon de Oliveira Conde \\ ORCID: https://orcid.org/0000-0002-3615-6328 \\ Federal University of Amazonas, Brazil \\ E-mail: nikeilaconde@ufam.edu.br
}

\begin{abstract}
This study aimed to evaluate in vitro the pharmacological stability of a herbal mouthwash based on Libidibia ferrea extract after aging, establishing its organoleptic and microbiological characteristics. It is a $7.5 \%$ hydroalcoholic extract from Libidibia ferrea pods, using the reflux decoction technique, and spray dried. The stability, $\mathrm{pH}$, sedimentation, density, and antimicrobial activity tests of the mouthwash were performed with the solutions stored after 24 months. Contaminant control was carried out by determining the total number of microorganisms and researching Salmonella sp., Escherichia coli, Pseudomonas aeruginosa, and Staphylococcus aureus. The formulation's antimicrobial activity against microorganisms present in the dental biofilm was analyzed: Streptococcus mutans, Streptococcus salivarius, Lactobacillus casei, and Candida albicans., The data were analyzed using the Tukey test to assess $\mathrm{pH}$ and density, and the other results were described using descriptive statistics., The color observed in the organoleptic characters, was "Ceramics", with a fluid/serous consistency, shiny appearance, and a strong minty, woody odor. In the sedimentation phase, the separation was observed, and the $\mathrm{pH}$ and density analyzes showed a mean value of 5.46 and $1.029 \mathrm{~g} / \mathrm{cm} 3$, respectively. The contaminant assessment test was negative for all
\end{abstract}


microorganisms surveyed, within 24 months. The mouthwash showed bactericidal/fungicidal activity against all the microorganisms tested at all concentrations for $S$. mutans and $C$. albicans. At concentrations $0.5 \mathrm{mg} / \mathrm{ml} \mathrm{for} S$. salivarius and $0.6 \mathrm{mg} / \mathrm{ml}$ for $L$ casei. It was concluded that after 24 months, the formulation of the mouthwash based on L. ferrea, its initial characteristics remained stable except for the homogeneity and $\mathrm{pH}$ of the solution.

Keywords: Quality control; Mouthwash; Herbal medicines; Antimicrobial activity.

\section{Resumo}

O objetivo deste estudo foi avaliar in vitro a estabilidade farmacológica de um enxaguatório bucal fitoterápico à base do extrato de Libidibia ferrea após envelhecimento, estabelecendo suas características organolépticas e microbiológicas. Trata-se de um extrato hidroalcóolico a 7,5\%, a partir da vagem de Libidibia ferrea, pela técnica de decocção por refluxo, e seco por aspersão. Os testes de estabilidade, pH, sedimentação, densidade e atividade antimicrobiana do enxaguatório foram realizados com as soluções armazenadas após 24 meses. Realizou-se o controle de contaminantes, através da determinação do número total de microrganismos e pesquisa de Salmonella sp., Escherichia coli, Pseudomonas aeruginosa e Staphylococcus aureus. Analisou-se a atividade antimicrobiana da formulação frente a microrganismos presentes no biofilme dental: Streptococcus mutans, Streptococcus salivarius, Lactobacillus casei e Candida albicans determinando-se a concentração inibitória mínima. Para avaliação do pH e densidade, os dados foram analisados pelo teste de Tukey e os demais resultados foram descritos pela estatística descritiva. Nos caracteres organolépticos, a coloração observada foi "Cerâmica", com consistência fluida/serosa, aspecto brilhante e odor forte amadeirado mentolado. Na sedimentação observou-se separação de fases e as análises de $\mathrm{pH}$ e densidade apresentaram como média o valor de 5,46 e 1,029 g/cm3, respectivamente. O teste de avaliação de contaminantes foi negativo para todos os microrganismos pesquisados, em 24 meses. $\mathrm{O}$ enxaguatório apresentou atividade bactericida/fungicida frente a todos os microrganismos testados em todas as concentrações para os microrganismos $S$. mutans e C. albicans e nas concentrações $0,5 \mathrm{mg} / \mathrm{ml}$ para o S.salivarius e $0,6 \mathrm{mg} / \mathrm{ml}$ para L. casei. Concluiu-se que após 24 meses, a formulação do enxaguatório bucal à base de L. ferrea suas características iniciais mantiveram-se estáveis com exceção da homogeneidade e pH da solução.

Palavras-chave: Controle de qualidade; Enxaguatório bucal; Medicamentos fitoterápicos; Atividade antimicrobiana.

\section{Resumen}

El objetivo de este estudio fue evaluar in vitro la estabilidad farmacológica de un enjuague bucal herbal a base de extracto de Libidibia ferrea tras la crianza, estableciendo sus características organolépticas y microbiológicas. Las pruebas de estabilidad, $\mathrm{pH}$, sedimentación, densidad y actividad antimicrobiana del colutorio se realizaron con las soluciones almacenadas a los 24 meses. El control de contaminantes se llevó a cabo determinando el número total de microorganismos e investigando Salmonella sp., Escherichia coli, Pseudomonas aeruginosa y Staphylococcus aureus. Se analizó la actividad antimicrobiana de la formulación frente a los microorganismos presentes en el biofilm dental: Streptococcus mutans, Streptococcus salivarius, Lactobacillus casei y Candida albicans, determinando la concentración mínima inhibitoria. Para evaluar el $\mathrm{pH}$ y la densidad, los datos se analizaron mediante la prueba de Tukey y los demás resultados se describieron mediante estadística descriptiva. En los caracteres organolépticos, el color observado fue "Cerámico", de consistencia fluida/serosa, aspecto brillante y fuerte olor a menta amaderada. En la fase de sedimentación se observó separación y los análisis de pH y densidad arrojaron como promedio el valor de 5.46 y $1.029 \mathrm{~g} / \mathrm{cm} 3$, respectivamente. La prueba de evaluación de contaminantes fue negativa para todos los microorganismos estudiados, en 24 meses. El enjuague bucal mostró actividad bactericida / fungicida contra todos los microorganismos probados en todas las concentraciones para los microorganismos $S$. mutans y $C$. albicans y en concentraciones de $0,5 \mathrm{mg} / \mathrm{ml}$ para $S$. salivarius y $0,6 \mathrm{mg} / \mathrm{ml}$ para $L$. casei. Se concluyó que luego de 24 meses, la formulación del enjuague bucal a base de L. ferrea, sus características iniciales permanecieron estables, a excepción de la homogeneidad y pH de la solución.

Palabras clave: control de calidad; enjuague bucal; Hierbas medicinales; Actividad antimicrobiana.

\section{Introduction}

Herbal therapies are used worldwide to treat health conditions. The compounds and extracts of natural products have been the object of study aimed at obtaining therapeutic agents that enable the prevention and treatment of numerous oral diseases (Martínez, Gómez \& Oh, 2017). Brazil is a country with a rich biological and cultural diversity, the consumption of products derived from plants is a popular practice and there is a growing interest in these products worldwide (Oliveira et al., 2020). Among the high biodiversity of medicinal plants used, Libidibia ferrea (L. ferrea), popularly known as juca or pau de ferro, is widely used in dentistry and folk medicine, due to its therapeutic anti-inflammatory, analgesic and antimicrobial properties (Conde et al., 2015; Cavalheiro et al., 2009; Pereira et al., 2012; Falcão et al., 2019). 
To verify the chemical compounds of the hydroalcoholic extract of L. ferrea, phytochemical studies were carried out and identified the presence of tannins, flavonoids, saponins, steroids and coumarins which have high enzymatic and antioxidant potential (Pedrosa et al., 2016). (Pedrosa et al., 2016).

Chromatographic and spectrophotometric studies were carried out with the extract of Libidibia ferrea, identifying phenolic compounds, highlighting their main constituents, the hydrolysable tannins (gallic acid and ellagic acid). Qualitative and quantitative analyzes demonstrated the separation and identification of these markers as well as the quantification of phenolic compounds by ultraviolet/visible (Ferreira et al., 2016).

L. ferrea has shown, through the results of studies, great potential, pointing to its use as a mouthwash aiming at the control of dental biofilm (Marreiro et al., 2014; Souza et al., 2020), a factor related to periodontal infections and dental caries, which are arguably the most common infectious pathologies in the oral cavity (Ferreira et al., 2013).

According to legal requirements, a herbal product must be known to be safe and effective, making it necessary to analyze numerous aspects ranging from the origin of the plant's raw material, formulation stability, and its physical-chemical parameters (Galvão, 2015).

Considering the therapeutic potential of the vegetable species L. ferrea, this study aimed to evaluate in vitro the pharmacological stability of a formulation in the form of a herbal mouthwash based on L. ferrea extract after aging.

\section{Methodology}

This study is a continuation of the survey by Venâncio et al. (2015) \& Souza et al. (2020) in which they evaluated the physicochemical properties of the extract and rinse based on Libidibia ferrea (228,022 - INPA) at 0, 30, 60, 90, 120 and 180 days, under three storage conditions. Thus, the formulation analyzed followed the steps described in the articles above, to obtain the raw material, extract preparation, and formulation.

It is a 7.5\% hydroalcoholic extract from L. ferrea pods prepared in the proportion 1:1 (500 mL of distilled water and $500 \mathrm{~mL}$ of $96 \%$ alcohol) and obtained by the reflux decoction technique, and spray dried (Spray Dryer). From this extract, the mouthwash was formulated according to the adapted methodology of Zanin et al. (2007). The components were: sodium benzoate, saccharin, glycerin, L. ferrea extract at 7.5\% (w/v), 80\% Tween, 20\% Tween, 20\% Tween, distilled water, mint essence and $10 \%$ sodium hydroxide.

\subsection{Formulation characterization}

The characterization tests of the mouthwash formulation ( $\mathrm{pH}$ test, density, sedimentation, organoleptic, and microbiological control) were performed with the solutions stored after 24 months.

The evaluation of organoleptic characters was based on changes in color, odor, brightness, and consistency. Color and brightness were analyzed in daylight. Consistency was assessed by touch. The smell of the emulsion was determined first, the intensity of the odor: none; weak; distinct or strong and then the sensation caused by the fragrance: aromatic; fruity; musty; rancid or woody according to the collegiate council Resolutions ("Resolução Diretoria Colegiada " - RDC) 211/05 and RDC $45 / 12$.

The $\mathrm{pH}$ was measured using the pHmeter (TEC2, TECNAL, Piracicaba, SP, Brazil). The determination of $\mathrm{pH}$ was performed by measuring the potential difference between two electrodes previously calibrated to appropriate standards ( $\mathrm{pH} 7.0$ and 4.0), immersed in the solution under examination (Farmacopeia brasileira, 2010).

Sedimentation was based on the rotational speed of test tubes containing the mouthwash, using the centrifuge (5804 R, EPPENDORF, Hamburg, Germany) at $3000 \mathrm{rpm}$ for 5 minutes, at room temperature, for observation with the naked eye, of a possible separation of the solution phases. 
For density, measurements were used in the dry pycnometer, water pycnometer, and pycnometer with the mouthwash. The relative density was calculated using the formula: $\mathrm{p}_{\text {(sample) }}=\mathrm{d}_{\text {(water) }} \mathrm{x}_{\text {(sample) }}+0,0012$.

The tests were done in triplicate, and the averages of the readings were used as a result.

\subsection{Microbiological evaluation for contaminant research}

For the microbiological control of the mouthwash, specific culture media were used. Soybean casein medium was used for aerobics and sabouraud agar for fungi and yeasts, to determine the total number of microorganisms. In the study of Salmonella sp., Escherichia coli, Pseudomonas aeruginosa, and Staphylococcus aureus, the media were bright green agar, mac conkey, cetrimide and mannitol salt, respectively.

\subsection{Total microorganism count}

They were prepared in a 1:10 ratio, using $100 \mu \mathrm{L}$ of the mouthwash and $900 \mu \mathrm{L}$ of peptonized water (Acumedia®, United States). Then they were diluted and homogenized in 1:10 proportions; 1: 100 and 1: 1000. After homogenization, the samples were pipetted and seeded in Petri dishes containing culture media Casein-soy agar for bacteria and Sabouraud dextrose agar (Difco®, France) for yeast, separately. The plates were incubated at $35^{\circ} \mathrm{C}$ for 24 and 48 and at $25^{\circ} \mathrm{C}$ for 5 to 7 days to search for bacteria and fungi. After this period, if there were suspicious colonies, the number of colony-forming units (CFU / $\mathrm{mL}$ ) would be determined.

\subsection{Research of Salmonella sp and Escherichia coli}

For the research of Salmonella $s p$ and E. coli, the experimental protocol described in Figure 1 was performed.

Figure 1 - Scheme for the search for Escherichia coli and Salmonella sp.

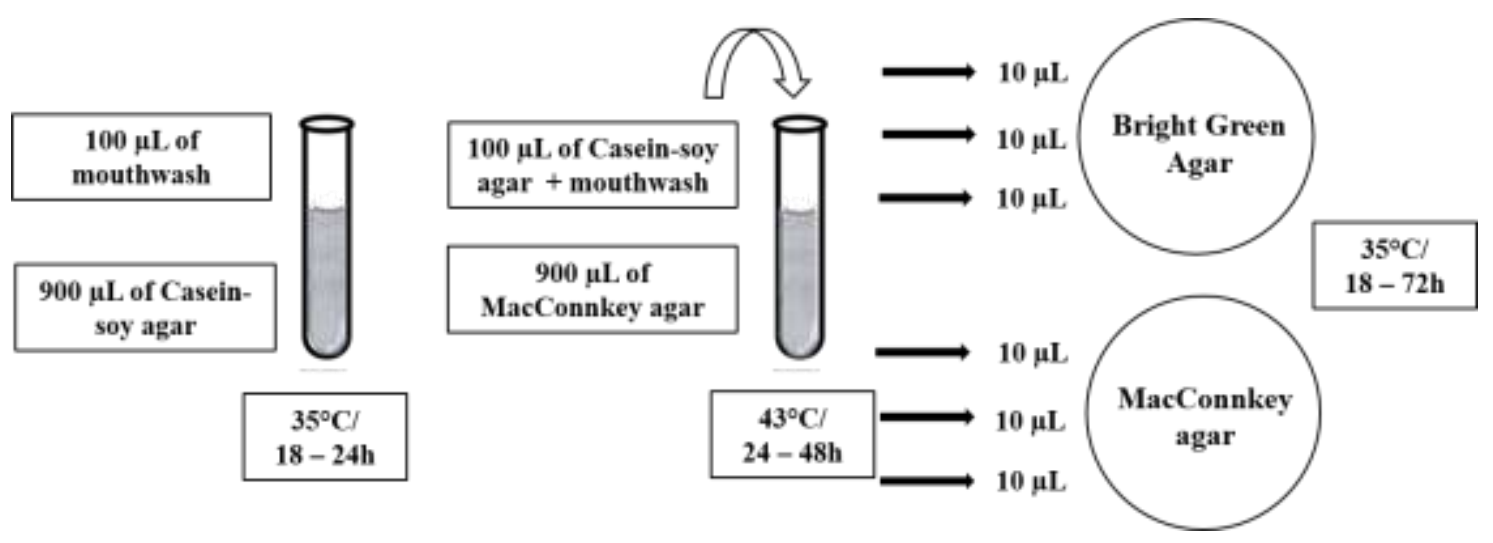

Source: Venâncio et al. (2015).

If there were suspicious colonies, they would be seeded in a tube containing triple sugar-iron agar (TSI) and incubated at $35^{\circ} \mathrm{C}$ for $24 \mathrm{~h}$. After this period, the number of colony-forming units (CFU / $\mathrm{mL}$ ) would be determined.

\subsection{Research of Staphylococcus aureus and Pseudomonas aeruginosa}

Aseptically, $100 \mu \mathrm{L}$ of the L. ferrea mouthwash was transferred to $900 \mu \mathrm{L}$ of casein soy broth. Then, it was homogenized and incubated at $35^{\circ} \mathrm{C}$ for $18-24 \mathrm{~h}$. After this period, a $10 \mu \mathrm{L}$ aliquot of the subculture was sown, in triplicate, on Cetrimide agar (Acumedia ${ }^{\circledR}$, United States) incubated at $35^{\circ} \mathrm{C}$ for $18-72 \mathrm{~h}$ for P. aeruginosa and $10 \mu \mathrm{L}$ of the subculture was sown on Agar mannitol salt for S. aureus research. 


\subsection{Evaluation of the CIM of $\boldsymbol{l}$. Ferrea extract and rinse}

\subsubsection{Testing microorganisms and inoculum preparation}

The microorganisms used were: S. mutans (CCT 3440), S. salivarius (NCTC 8618), L.casei (ATCC 335) and C. albicans (ATCC 11006). The bacterial strains were reactivated in a nutritious BHI (Brain Heart Infusion - DIFCO), incubated at $37^{\circ} \mathrm{C}$ for $24 \mathrm{~h}$ in aerophilic, for S. salivarius and $L$. casei, and in microaerophilia for S. mutans. For C. albicans, reactivation was performed in Sabouraud nutrient broth, incubated $\left(37^{\circ} \mathrm{C} / 48 \mathrm{~h}\right)$ in aerophilia, and subsequently, the yeast was subcultured on Sabouraud agar under the same incubation conditions.

\subsubsection{Determination of the antimicrobial activity of $L$. ferrea extract and rinse}

The antimicrobial activity of the L. ferrea extract and rinse was determined according to the Minimum Inhibitory Concentration (MIC) methodology in microdilution proposed by NCCLS (2003), Andrews (2001), adapted by Sampaio et al., (2009). The $0.12 \%$ chlorhexidine digluconate was used as a positive control.

96-well microplates were used, containing $100 \mu \mathrm{L}$ in each well with different concentrations of the test substances. On the board, the columns were distributed in the numbers 1 to 12 and the lines in the letters "A" to "H". The dilution system was controlled by the volume of the test products, occupying wells 1 to 11. In the same wells, a standard amount of inoculum $(20 \mu \mathrm{L})$ was added, and the final volume was supplemented with the medium. The first column represented the sterility of the test substance, mouthwash or extract + medium without bacteria. The 12th represented the viability of the bacteria, medium + inoculum, without test product. Line F represented $0.12 \%$ chlorhexidine digluconate. After filling all wells, the microplates were sealed with parafilm and incubated at $37^{\circ} \mathrm{C}$ for $24 \mathrm{~h}$, in aerophilia for C. albicans, L. Casei, and S. salivarius and microaerophilia for $S$. mutans. After $24 \mathrm{~h}, 30 \mu \mathrm{L}$ of $0.01 \%$ resazurin was added, and the plates were incubated again for $1 \mathrm{~h}$. The absence of color change in the wells was interpreted as a microorganism sensitive to the tested solution.

$100 \mu \mathrm{L}$ of wells containing rinse / juca extract in different concentrations were removed, seeded in Petri dishes with BHI agar and incubated at $37^{\circ} \mathrm{C}$ in aerophilia and microaerophilia, according to the tested microorganism, for 24 and $48 \mathrm{~h}(S$. mutans) to confirm the presence of viable bacteria.

\subsection{Statistical Analysis}

The results obtained through MIC, evaluation of contaminants, stability, and sedimentation, were tabulated and described by descriptive statistics. In assessing $\mathrm{pH}$ and density, data were presented using tables, calculating the mean and standard deviation (SD) for quantitative data that showed normal distribution using the Tukey test (Arango, 2001; Vieira, 2004).

\section{Results and Discussion}

Phytotherapy is characterized by being a natural therapeutic option. Although its use is considered ancient, the use of medicinal plants to treat oral diseases or to treat systemic diseases with oral manifestations is still little explored (Oliveira et al., 2007). However, in recent years, research related to natural products has grown significantly in the face of an increase in the search for newer, more efficient products, with less toxicity, more significant pharmacological activity, and biocompatible, in addition to more accessible costs for the population (Francisco, 2010; Jain \& Jain, 2016).

According to Castilho et al. (2007), employment in Dentistry can be considered a support tool in the therapy of various oral pathologies, such as in the prevention and treatment of periodontal disease, dental caries, and oral candidiasis. For the improvement of new products used in Dentistry and to prove their effectiveness, they need to be subjected to several tests, 
trying to visualize their clinical performance when used in the oral cavity, to enable the use of the product in the daily clinic (Evangelista et al., 2013).

The National Health Surveillance Agency (ANVISA), based on the guidelines of national policies, carried out an extensive review of the legislation for the sector of medicinal plants and herbal medicines, drafted new standards, which provide for the minimum quality requirements for drugs, inputs, plant drugs, medicines and products for the health, including parameters for quality control of medicinal plants and / or their derivatives, such as the verification of the physical, chemical, biological and microbiological characteristics of a pharmaceutical product in the expected validity, whose final objective is to obtain products that are within the quality of the standards required (Brasil, 2013).

To evaluate, in vitro, the pharmacological stability of a mouthwash based on L. ferrea in the sampling periods of 0 , 30, and 60 days, Venâncio et al. (2015) proposed a study. It concluded that the mouthwash showed stability conditions, as well as the absence of contaminants. In continuity, Souza et al. (2020) analyzed the formulation above to assess pharmacological stability, in three storage conditions (room temperature, air conditioning, and refrigerator) and in six time intervals $(0,30,60$, 90, 120 and 180 days) presenting favorable conditions of stability and absence of contaminants. Thus, the present study aimed to evaluate, in vitro, the same formulation analyzed in the study by Venâncio et al. (2015) and Souza et al. (2020), verifying if its characteristics remained stable after 24 months.

Regarding the organoleptic characteristics evaluated in this study, the formulation presented after 24 months of storage, "ceramic" color (Coral ${ }^{\circledR}$ color scale), fluid / serous consistency, shiny appearance, and intense woody and minty odor, with consistent and satisfactory standards according to the parameters described by the Brazilian Pharmacopoeia (Farmacopeia brasileira, 2010). Corroborating the results of Venâncio et al. (2015) in which the mouthwash showed dark brown color, pleasant odor, and uniform appearance.

According to Isaac et al. (2008), the appearance of a phytocosmetic, about color and homogeneity, is important from a commercial point of view. These can influence the purchase by the consumer, who might not be attracted by the appearance of the product. Besides, they stated that changes in odor might be related to microbial contamination, even when there is no visual change, thus stressing the relevance of developing a protocol for the study of phytochemical physicochemical stability.

Regarding the physical-chemical aspects, the formulation had an average $\mathrm{pH}$ of 5.46, and there was phase separation as for the sedimentation test and density showed an average of $1.029 \mathrm{~g} / \mathrm{cm}^{3}$.

The initial $\mathrm{pH}$ values of the $L$. ferrea mouthwash obtained in the study by Venâncio et al. (2015), presented an average of $6.20,6.15$, and 5.84, at times 0,30 and 60 days, respectively. In the present study, after aging, the $\mathrm{pH}$ was approximately 5.27 , demonstrating a decline in $\mathrm{pH}$ values overtime.

The results obtained by Marreiro et al. (2014a), also showed a decrease in the average $\mathrm{pH}$ values of the tested juca mouthwash during the experiment, with a statistically significant difference in $\mathrm{pH}$, at the level of $5 \%$, between the periods of 0 and 60 days, however, in the periods from 0 to 30 days and 30 to 60 days, this statistical difference was not observed when the Tukey test was performed, with the $\mathrm{pH}$ of the formulation around 5.5. According to Souza et al. (2020), when comparing subsequent sample periods, there was a statistically significant $\mathrm{pH}$ difference in the periods of 60-90 ( $\mathrm{p}<0.001$ ).

In the study by Marreiro et al. (2014a) where the same experiment was also performed using a formulation based on L. ferrea extract, no phase separation was observed in any three experimental periods ( 0,30 , and 60 days). According to Isaac et al. (2008), stability is not ensured by the absence of phase separation. Therefore, the presence of sedimentation of the solution based on L. ferrea overtime, refers to the need to homogenize the mouthwash before use, through agitation.

Venâncio et al. (2015), in the sedimentation test, did not observe phase separation or sediment precipitation from the L. ferrea mouthwash in any of the three experimental periods when subjected to centrifugation. However, according to Souza 
et al. (2020), this characteristic was not stable after 90, 120, and 180 days under different storage conditions. It corroborates with the present study, since after 24 months, the formulation presented phase separation.

As for density, in the results by Venâncio et al. (2015), it was found that the variation was acceptable in the initial experimental periods, noticing a statistical difference over time, when the Tukey test was performed, but without interfering in the final formulation characteristic. The results by Souza et al. (2020) regarding sedimentation found that there was no statistically significant difference when comparing sample times and storage environments. Corresponding to the results

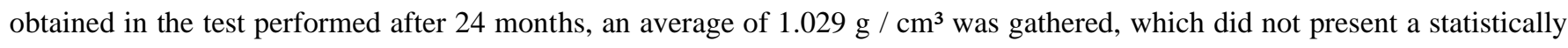
significant difference about the time of $60,90,120$, and 180 days.

The study by Marreiro et al. (2014a), showed that there was a variation in the density values, decreasing in the experimental periods, with the statistical difference in the periods from 0 to 60 days and remaining without a statistical difference in density in the periods referring to 0 and 30 days and 30 to 60 days. It suggests that these variations may have occurred due to water loss or even the volatility of mouthwash, as Isaac et al. (2008) described.

Ferreira and Souza (2007), confirmed the importance of the stability study by emphasizing that it is indispensable for the standardization of herbal products, as this shows the time for which the drug retains its integrity and can be affected by factors such as temperature, $\mathrm{pH}$, luminosity and air, in addition to the fact that instability can modify three main points: quality, efficiency, and safety.

The objective of microbiological control is to determine the total number of microorganisms in non-sterile cosmetic and vegetable products, the identification of pathogenic microorganisms can ensure good quality products (Brasil, 2013; Evangelista et al., 2013). Therefore, according to the results obtained in the present study, the mouthwash of L. ferrea under conditions in tested culture media. There was no indication of the presence of microorganisms (bacteria, fungi or yeasts) Salmonella sp., Escherichia coli, Pseudomonas aeruginosa, and Staphylococcus aureus. They were corroborated with Venâncio et al. (2015) and Souza et al. (2020), since there was no indication of the presence of microorganisms in all intervals in the studies performed.

Several studies have published data on the antimicrobial activity of several plants against microorganisms present in the oral cavity, indicating their use as new antibacterial herbal products (Rocha et al., 2013; Jain \& Jain, 2016; Conde et al., 2015; Oliveira et al., 2020). And according to research by Marreiro et al. (2014a), Conde et al. (2015) and Venâncio et al. (2015), the results showed a positive perspective for the formulation of mouthwash from the extract of $L$. ferrea, which has shown promise regarding the production of a new antimicrobial for Dentistry.

The evaluation of the antimicrobial activity of the L. ferrea mouthwash against strains of S. mutans, S. salivarius, L. Casei, and C. albicans, showed that the mouthwash showed bactericidal / fungicidal antimicrobial activity against all the microorganisms tested in all concentrations for S. mutans and C. albicans and concentrations $0.5 \mathrm{mg} / \mathrm{mL}$ for S. salivarius and $0.6 \mathrm{mg} / \mathrm{mL}$ for L. casei. It showed bacteriostatic activity at a level of $0.55 \mathrm{mg} / \mathrm{mL}$ against L. casei and $0.4 \mathrm{mg} / \mathrm{mL}$ against $S$. salivarius. As for the extract of L. ferrea, it also showed bactericidal action in all concentrations against the microorganisms $S$. mutans and C. albicans and in concentrations $0.041 \mathrm{mg} / \mathrm{mL}$ and $0.048 \mathrm{mg} / \mathrm{mL}$ for L. casei and S. Salivarius, respectively. The L. ferrea extract showed bacteriostatic activity at concentrations of $0.037 \mathrm{mg} / \mathrm{mL}$ for L. casei and $0.03 \mathrm{mg} / \mathrm{mL}$ for $S$. salivarius. Figures 2, 3, 4 and 5 shows the microdilution plating of the extract against S. mutans, C. albicans, L. casei and S. salivarius. 
Research, Society and Development, v. 10, n. 10, e487101018996, 2021

(CC BY 4.0) | ISSN 2525-3409 | DOI: http://dx.doi.org/10.33448/rsd-v10i10.18996

Figure 2 - Plating of lines D1 to D12 of the microdilution of Libidibia ferrea extract against Streptococcus mutans.
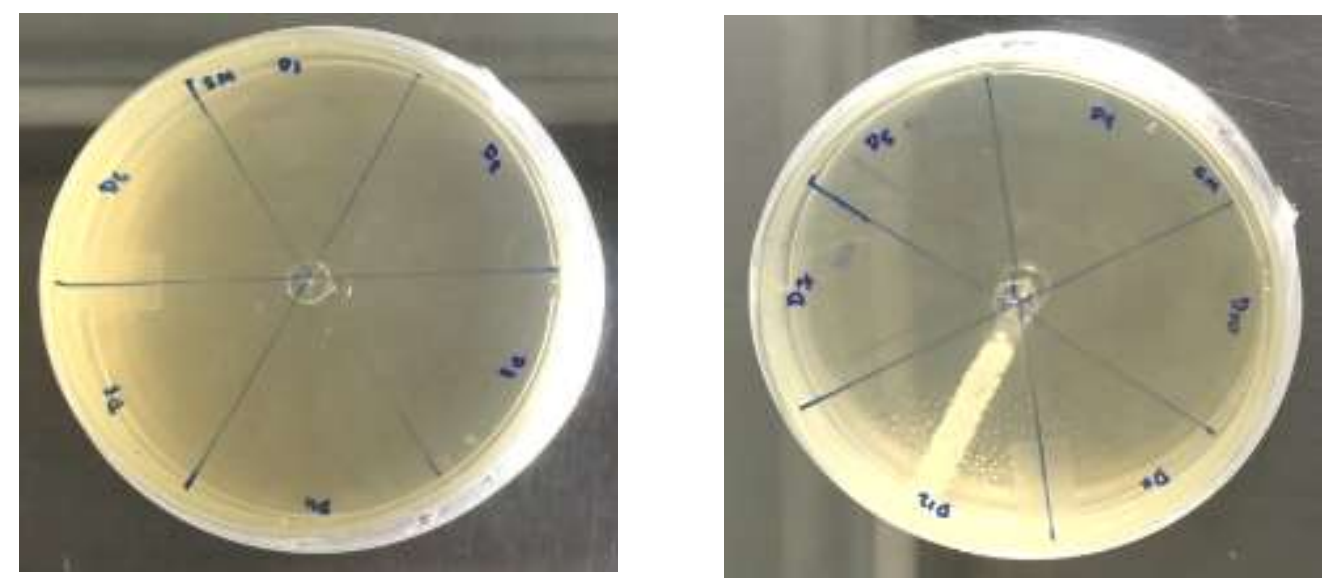

Source: Authors.

Figura 3 - Plating of lines D1 to D12 of the microdilution of Libidibia ferrea extract against Candida albicans
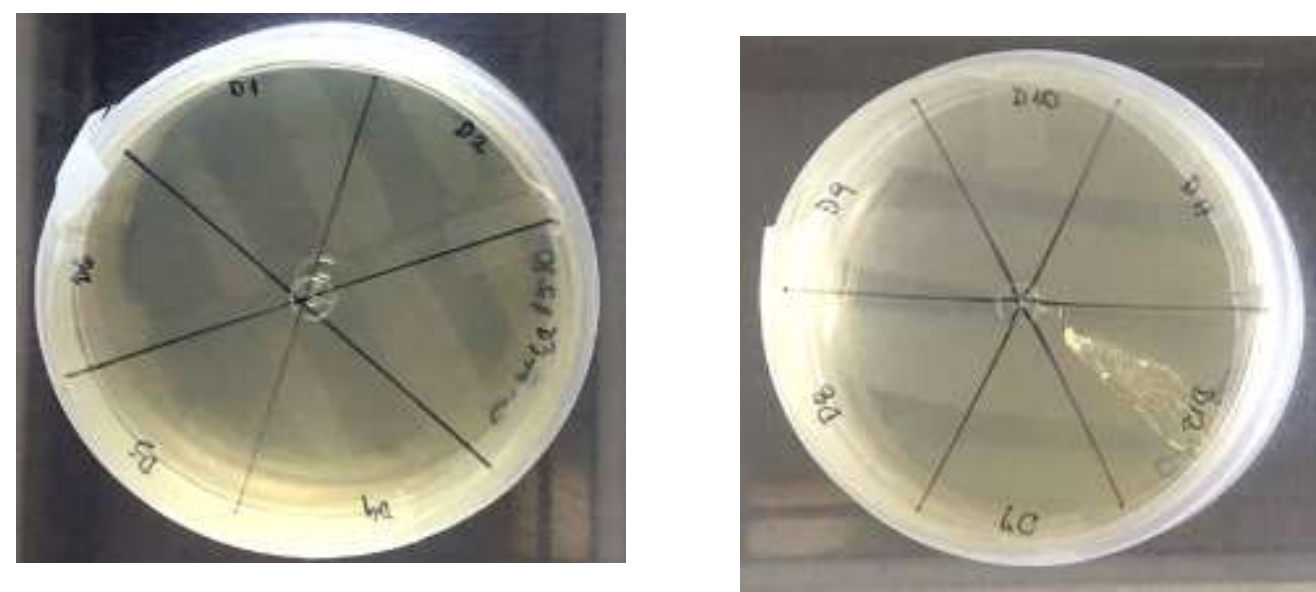

Source: Authors.

Figure 4 - Plating of lines D1 to D12 of the microdilution of Libidibia ferrea extract against Lactobacillus casei.
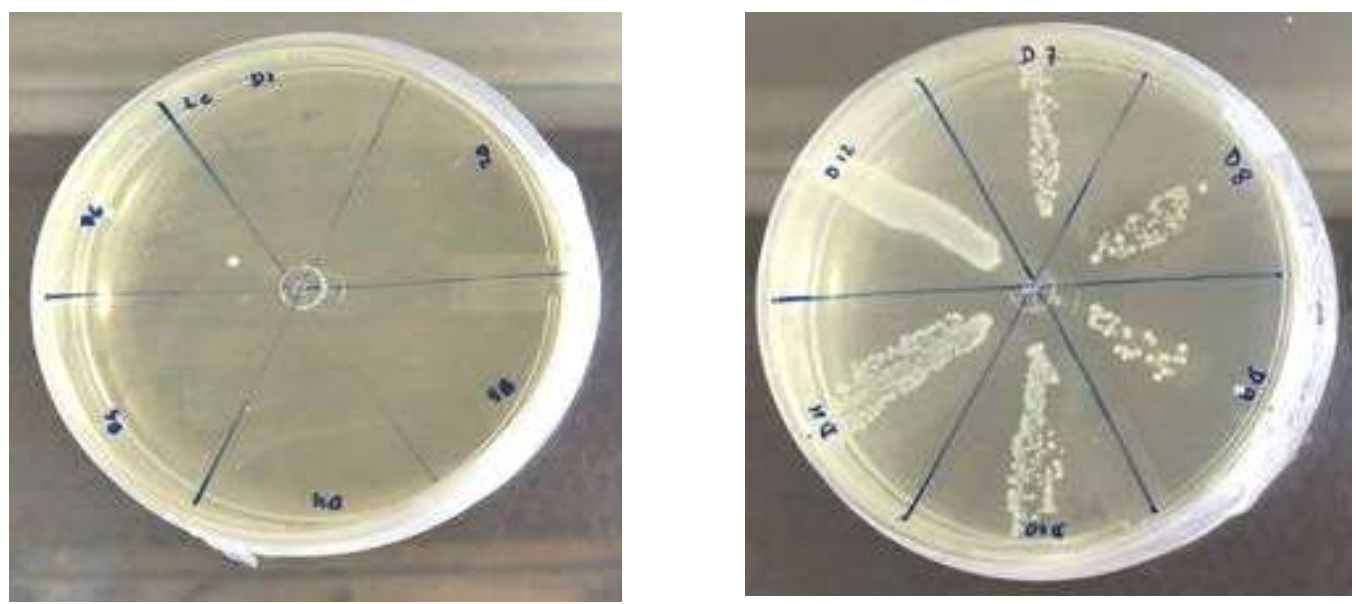

Source: Authors. 
Figure 5 - Plating of lines E1 to E12 of the microdilution of Libidibia ferrea extract against Streptococcus salivarius.
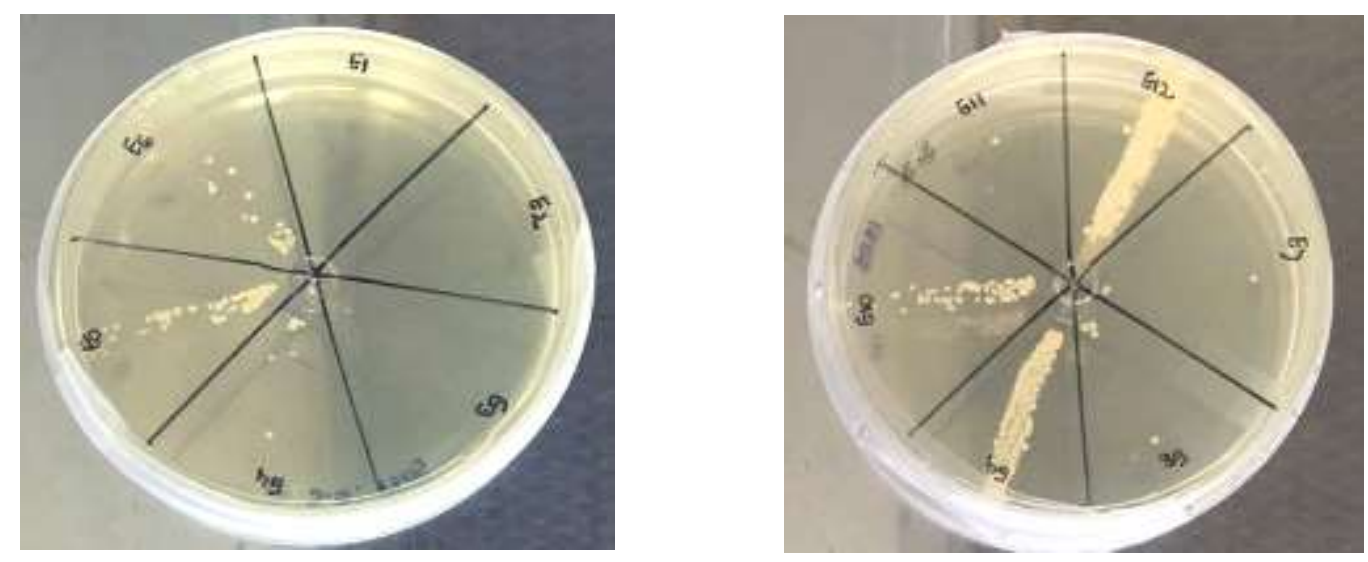

Source: Authors.

In the study by Venâncio et al. (2015), with the same mouthwash, bactericidal action was observed in concentrations of $0.55 \mathrm{mg} / \mathrm{mL} ; 0.6 \mathrm{mg} / \mathrm{mL}$ and $0.65 \mathrm{mg} / \mathrm{mL}$ for S. mutans, S. oralis and S. salivarius and $0.25 \mathrm{mg} / \mathrm{mL}$ for L.casei and C.albicans and bacteriostatic action at a concentration of $0,3 \mathrm{mg} / \mathrm{mL}$ against $S$. mutans, S. oralis and S. salivarius, proving that the L. ferrea mouthwash 30 months after its formulation still has antimicrobial activity against bacteria present in the dental biofilm.

As for the extract of L. ferrea, it also showed bactericidal action in all concentrations against the microorganisms $S$. mutans and C. albicans and in concentrations $0.041 \mathrm{mg} / \mathrm{mL}$ and $0.048 \mathrm{mg} / \mathrm{mL}$ for L. casei and S. Salivarius, respectively. The L. ferrea extract showed bacteriostatic activity at concentrations of $0.037 \mathrm{mg} / \mathrm{mL}$ for L. casei and $0.03 \mathrm{mg} / \mathrm{mL}$ for $S$. salivarius.

C. albicans and S.mutans were the least resistant microorganisms in the present study since all test substances had fungicidal / bactericidal action at all concentrations tested.

Marreiro et al. (2014a) evaluated a mouthwash based on L. ferrea, using the same methodology as the present study and resulted in bactericidal antibacterial activity against the strains of S. mutans, S. oralis, and L. casei, with MIC at concentrations of $4.375 \mathrm{mg} / \mathrm{mL}, 3.750 \mathrm{mg} / \mathrm{mL}$ and $4.375 \mathrm{mg} / \mathrm{mL}$, respectively, however, compared to S. salivarius neither the extract nor the mouthwash of juca showed antimicrobial activity, differently from the results found in this research, where both the extract and the mouthwash of L ferrea showed bactericidal and bacteriostatic activity against this microorganism. In continuity, Marreiro et al. (2020) analyzed the antibacterial of the extract and the mouthwash of Libidibia ferrea L. against oral microorganisms, using the same test as the study mentioned above, demonstrating that the $0.6 \%$ L. ferrea L. extract presented antibacterial bactericidal activity against $S$ mutans, S. oralis and L. casei at concentrations of 4,375 $\mu \mathrm{g} / \mathrm{ml} ; 3750 \mathrm{ug} / \mathrm{ml} ; 4.375$ $\mu \mathrm{g} / \mathrm{ml}$, respectively.

Conde et al. (2015) evaluated the antimicrobial activity of plants from the Amazon, including L. ferrea, on microorganisms from the dental biofilm, by determining the MIC by diffusion in solid medium. The juca showed inhibition halos of 21 to $24 \mathrm{~mm}$ at a concentration of $500 \mathrm{mg} / \mathrm{mL}$ and halos of 14 to $15 \mathrm{~mm}$ at a concentration of $62.5 \mathrm{mg} / \mathrm{mL}$ (1: 8) for the microorganisms tested and the best results were reached against S. mutans, S. sobrinus and L. casei, with 15 mm halos at 1 : 8 dilution.

Sampaio et al. (2009) researched the in vitro antibacterial activity of the L. ferrea fruit extract against the same oral pathogens, using the same methodology as in the present study, concluding that the extract was effective against the microorganisms tested at concentrations of 25, 40, 66, 100 and $66 \mu \mathrm{g} / \mathrm{mL}$ for C. albicans, S. mutans, S. salivarius, S. oralis, 
and L. casei, respectively. Theses results corroborate the work of Venâncio et al. (2015), only concernig to $S$. mutans and with the present study, solely for C. albicans.

\section{Conclusion}

With the growing interest in the confirmation and scientific validation of plants' effects, much research has been carried out with a wide variety of plant species. L. ferrea has shown excellent results in research involving the control of microorganisms related to oral pathologies. Based on the results obtained, it can be concluded that after aging: The $L$. ferrea mouthwash presented favorable conditions of stability, with its initial characteristics stable, except for the homogeneity and $\mathrm{pH}$ of the solution, and there was an absence of contaminants in all experimental periods. Both the mouthwash and L. ferrea extract showed bactericidal and fungicidal antimicrobial activity against microorganisms from the dental biofilm.

\section{References}

Agência Nacional de Vigilância Sanitária - ANVISA. Farmacopéia brasileira, 2010. (5th ed.), ANVISA. Parte I e II.

Andrews, J. M. (2001). Determination of minimum inhibitory concentrations. Journal of Antimicrobial Chemotherapy, 48, 5-16. 0.1093/jac/48.suppl_1.5 Arango, H. G. (2001). Bioestatística teórica e computacional. Guanabara Koogan.

Brasil. Ministério da Saúde. Agência Nacional de Vigilância Sanitária, 2005. Resolução RDC nº 211, de 14 de julho de 2005 . Estabelece a Definição e a Classificação de Produtos de Higiene Pessoal, Cosméticos e Perfumes, conforme Anexo I e II desta Resolução e dá outras definições. Diário Oficial da União. Brasília, 14 julho 2005: http://www.agora.mfa.gr/agora/images/docs/ radE8A2DRDC_211_2005.pdf

Brasil. Ministério da Saúde. Agência Nacional de Vigilância Sanitária, 2012. Resolução RDC no 45, de 9 de agosto de 2012 . Dispõe sobre a realização de estudos de estabilidade de insumos farmacêuticos ativos. Diário Oficial da União. Brasília, 9 agosto 2012 http://bvsms.saude.gov.br/bvs/saudelegis/anvisa/2012/rdc0045_09_08_2012.htm

Brasil. Ministério da Saúde. Agência Nacional de Vigilância Sanitária, 2013. Resolução RDC nº 13, de 14 de março de 2013. Dispõe sobre as Boas Práticas de Fabricação de Produtos Tradicionais Fitoterápicos. Diário Oficial da União. Brasília, 14 março 2013 http://www.licencasanitaria.com/2013/03/rdc-132013norma-para-fabricacao-de.html

Castilho, A. R., Murata, R. M., \& Pardi, V. (2007). Produtos Naturais em Odontologia. Revista Saúde, 1(1), 11-19.

Cavalheiro, M. G., Farias, D. F., Fernandes, G. S., Nunes, E. P., Cavalcanti, F. S., Vasconcelos, I. M., Melo, V. M. M., \& Carvalho, A. F. U. (2009). Atividades biológicas e enzimáticas do extrato aquoso de sementes de Caesalpinia ferrea Mart., Leguminosae. Revista Brasileira de Farmacognosia, 19(2b), 586-91. http://dx.doi.org/10.1590/ S0102-695X2009000400014.

Conde, N. C. O., Pereira, M. S. V., Bandeira, M. F. C. L., Venâncio G. N., Oliveira, G. P., \& Sampaio, F. C. (2015). In vitro antimicrobial activity of plants of the Amazon on oral biofilm micro-organisms. Revista Odonto Ciência, 30(4), 179-183. https://doi.org/10.15448/1980-6523.2015.4.17794

Evangelista, S. S., Sampaio, F. C., Parente, R. C., \& Bandeira, M. F. C. L. (2013). Fitoterápicos na odontologia: estudo etnobotânico na cidade de Manaus. Revista Brasileira de Plantas Medicinais, 15(4), 513-9. https://doi.org/10.1590/S1516-05722013000400007

Falcão, T. R., Rodrigues, C. A. O., Araújo, A. A., Medeiros, C. A. C. X., Soares, L. A. L., Ferreira, M. R. A., Vasconcelos, R. C., Araújo Júnior, R. F., Lopes, M. L. D. S., \& Guerra, G. C. B. (2019). Crude extract from Libidibia ferrea (Mart. ex. Tul.) L.P. Queiroz leaves decreased intra articular inflammation induced by zymosan in rats. BMC Complementary and Alternative Medicine, 19(47), 1-10. 10.1186/s12906-019-2454-3.

Ferreira, A. C. R., Queiroz, A. P. G., Pamponet, G. P., Queiroz, A. P. G., Costa, C. R., Belizário, I. C., Ferreira, K. E., Rocha, L. R., \& Pereira, V. F. G. C. (2013). Doença Periodontal: Um mal que pode ser evitado? Periodontia, 23(3), 15-23.

Ferreira, M. R. A., Fernandes, M. T. M., Silva, W. A. V., Bezerra, I. C. F., Souza, T. P., Pimentel, M. F., \& Soares, L. A. L. (2016). Chromatographic and Spectrophotometric Analysis of Phenolic Compounds from Fruits of Libidibia ferrea Martius. Pharmacognosy Magazine, 12(2), 285-91. 10.4103/09731296.182165

Ferreira, A. O., \& Souza, G. F. (2007). Preparações orais líquidas. (2nd ed.), Pharmabooks.

Francisco, K. S. (2010). Fitoterapia: uma opção para o tratamento odontológico. Revista Saúde, 4(1), 18-24.

Galvão, M. A. M. Estabelecimento de método por uv/vis para controle de qualidade das cascas e frutos de libidibia ferrea (MART. EX TUL.) L.P. QUEIROZ. 2015. 81 f. Dissertação (Mestrado em Inovação Terapêutica) - Universidade Federal de Pernambuco, Recife.

Isaac, V. L. B., Cefali, L. C., Chiari, B. G., Oliveira, C. C. L. G., Salgado, H. R. N., \& Corrêa, M. A. (2008). Protocolo para ensaios físico-químicos de estabilidade de fitocosméticos. Revista de Ciências Farmacêuticas Básica e Aplicada, 29(1), 81-96.

Jain, I., \& Jain, P. (2016). Comparative evaluation of antimicrobial efficacy of three diferente formulations of mouth rinses with multi-herbal mouth rinse. Journal of Indian Society of Pedodontics and Preventive Dentistry, 34, 315-23. 10.4103/0970-4388.191409 
Marreiro, R. O., Bandeira, M. F. C. L., Almeida, M. C., Coelho, C. N., Venâncio, G. N., \& Conde, N. C. O. (2014). Avaliação de citotoxicidade de um enxaguatório bucal contendo extrato de Libidibia ferrea. Brazilian Research in Pediatric Dentistry and Integrated Clinic, 14(3), 34-42. http://dx.doi.org/10.4034/PBOCI.2014.14s3.04

Marreiro, R. O., Bandeira, M. F. C. L., Souza, T. P., Almeida, M. C., Bendaham, K., Venâncio, G. N., Rodrigues, I. C., Coelho, C. N., Milério, P. S. L. L., Oliveira, G. P., \& Conde, N. C. O. (2014 $\left.{ }^{\mathrm{a}}\right)$. Evaluation of the stability and antimicrobial activity of an ethanolic extract of Libidibia ferrea. Clinical, Cosmetic and Investigational Dentistry, 28(6), 9-13. 10.2147/CCIDE.S54319. eCollection 2014.

Marreiro, R. O., Bandeira, M. F. C. L., Toda, C., Sampaio, F. C., Souza, T. P., Venâncio, G. N., Souza, W. M., \& Conde, N. C. O. (2020). Antimicrobial Activity of a Formulation of Libidibia ferrea L. against Microorganisms of the Dental Biofilm. Advances in Microbiology, 10, 434-442. https://doi.org/10.4236/aim.2020.109032

Martínez, C. C., Gómez, M. D., \& Oh, M. S. (2017). Use of traditional herbal medicine as an alternative in dental treatment in Mexican dentistry: a review. Pharmaceutical biology, 55(1), 1992-1998.

Nccls. (2003). Performance Standards for Antimicrobial Disk Susceptibility Tests; Approved Standard- Eighth Edition. NCCLS document M2-A8 [ISBN 156238-485-6]. NCCLS, 940 West Valley Road, Suite 1400, Wayne, Pennsylvania. 2003: 19087-1898.

Oliveira, F. Q., Gobira, B., Guimarães, C., Batista, J., Barreto, M., \& Souza, M. (2007). Espécies vegetais indicadas na Odontologia. Revista Brasileira de Farmacognosia, 17(3), 466-76. https://doi.org/10.1590/S0102-695X2007000300022

Oliveira, E. H., Gonçalves, T. V. S. R., Verde, R. M. C. L., Holanda, E. C., Pereira, S. T., \& Nunes, L. C. C. (2020). Avaliação antimicrobiana do extrato seco obtido da casca e arilo da Punica granatum. Research, Society and Development, 9(8), e 461985941. doi:http://dx.doi.org/10.33448/rsd-v9i8.5941

Pedrosa, T. N., Barros, A. O., Nogueira, J. R., Fruet, A. C., Rodrigues, I. C., Calcagno, D. Q., Smith, M. A. C., Souza, T. P., Barros, S. B. M., Vasconcellos, M. C., Silva, F. M. A., Koolen, H. H. F., Maria-Engler, S. S., \& Lima, E. S. (2016). Anti-wrinkle and anti-whitening effects of jucá (Libidibia ferrea Mart.) extracts. Archives of Dermatological Research, 308(9), 643-654. 10.1007/s00403-016-1685-0.

Pereira, L. P., Silva, R. O., Bringel, P. H. S. F., Silva, K. E. S., Assreuy, A. M. S., \& Pereira, M. G. (2012). Polysaccharide fractions of Caesalpinia ferrea pods: Potential anti-inflammatory usage. Journal of Ethnopharmacology, 139(2), 642-9. 10.1016/j.jep.2011.12.012. Epub 2011 Dec 13.

Rocha, E. A. L. S. S., de Carvalho, A. V. O. R., de Andrade, S. R. A., \& Trovão, D. M. M. B. (2013). In vitro Antimicrobial Activity of Hydroalcoholic Extracts from Brazilian Northeastern Medicinal Plants against Streptococcus. Pesquisa Brasileira em Odontopediatria e Clínica Integrada. 13(3), 233-38. 10.4034/PBOCI.2013.133.02

Sampaio, F. C., Pereira, M. S. V., Dias, C. S., Costa, V. C. O., Conde, N. C. O., \& Buzalaf, M. A. R. (2009). In vitro antimicrobial activity of Caesalpinia ferrea Martius fruits against oral pathogens. Journal of Ethnopharmacology, 124(2), 289-94. 10.1016/j.jep.2009.04.034. Epub 2009 May 3.

Souza, L. A. L., Melo, K. S., Gomes, L. S. S., Souza, T. P., Bandeira, M. F. C. L., Toda, C., \& Conde, N. C. O. (2020). Quality control of a formulation mouthwash based on Libidibia Ferrea L. Brazilian Journal of Development, 6(7), 47236-47246. 10.34117/bjdv6n7-383

Venâncio, G. N., Rodrigues, I. C., Souza, T. P., Marreiro, R. O., Bandeira, M. F. C. L. \& Conde, N. C. O. (2015). Herbal Mouthwash Based on Libidibia ferrea: Microbiological Control, Sensory Characteristics, Sedimentation, $\mathrm{pH}$ and Density. Revista de Odontologia da UNESP, 44(2), 118-124. https://doi.org/10.1590/1807-2577.1064

Vieira, S. (2004). Bioestatística, tópicos avançados. Elsevier.

Zanin, S. M. W., Miguel, M. D., Barreira, S. M. W., Nakashima, T., Cury, C. D., \& Costa, C. C. (2007). Mouthwasher: Active Principles and Development of a Formula with Hydroalcoholic Extract of Salvia officinalis L. Visão Acadêmica, 8, 19-24. https://doi.org/10.5380/acd.v8i1.11661 